\title{
Enhanced Pollution Removal with Heat Reclamation in a Small Hungarian Wastewater Treatment Plant
}

\author{
Viola Somogyi"1, Viktor Sebestyén ${ }^{2}$, Zsófia Kovács ${ }^{3}$, Réka H. Hargitai', \\ Endre Domokos 5 \\ ${ }^{1}$ Institute of Environmental Engineering, University of Pannonia, Egyetem u. 10, 8200 Veszprém, Hungary \\ e-mail: somogyiv@uni-pannon.hu \\ ${ }^{2}$ Institute of Environmental Engineering, University of Pannonia, Egyetem u. 10, 8200 Veszprém, Hungary \\ e-mail: sebestyenv@almos.uni-pannon.hu \\ ${ }^{3}$ Institute of Environmental Engineering, University of Pannonia, Egyetem u. 10, 8200 Veszprém, Hungary \\ e-mail: zsofiakovacs@almos.uni-pannon.hu \\ ${ }^{4}$ Institute of Environmental Engineering, University of Pannonia, Egyetem u. 10, 8200 Veszprém, Hungary \\ e-mail: hreka03@gmail.com \\ ${ }^{5}$ Institute of Environmental Engineering, University of Pannonia, Egyetem u. 10, 8200 Veszprém, Hungary \\ e-mail: domokose@uni-pannon.hu \\ Cite as: Somogyi, V., Sebestyén, V., Kovács, Z., Hargitai, R. H., Domokos, E., Enhanced Pollution Removal with Heat \\ Reclamation in a Small Hungarian Wastewater Treatment Plant, J. sustain. dev. energy water environ. syst., 6(3), \\ pp 494-504, 2018, DOI: https://doi.org/10.13044/j.sdewes.d6.0200
}

\begin{abstract}
The aim of the research is to outline the possibilities of utilizing waste heat in small municipal wastewater treatment plants. The facility, which was chosen as case-study, accepts about $2,300 \mathrm{~m}^{3}$ of raw sewage daily. In wintertime the wastewater temperature decreases to $10-14{ }^{\circ} \mathrm{C}$ which results in lower nitrification capacity based on measurement and validated model results. The excess heat of the wastewater would serve to increase the temperature of the aeration tank in order to enhance the microbiological activity and thus the efficiency of pollutant removal. The amount of reusable waste heat is calculated and with the help of dynamic simulation the effluent quality was determined to compare it with the original results. Increasing the temperature by $6{ }^{\circ} \mathrm{C}$ in the aerated tank, ammonium removal could be improved by $61 \%$. This way not only the heat, but the nutrient pollution could be mitigated, too.
\end{abstract}

\section{KEYWORDS}

Waste heat recovery, Wastewater treatment, Activated sludge model, Dynamic simulation, Nitrogen removal.

\section{INTRODUCTION}

Wastewater treatment processes - no matter how advanced - are mostly end-of-pipe technologies focusing on removing the pollutants from the effluent before discharging it to the receiving water body [1]. Reuse of treated municipal wastewater is an issue only in countries where physical water scarcity has to be faced [2] for example in Namibia [3] or Israel [4] and reclamation of materials is in many cases unsolved [5]. Since (fossil fuelled) energy is needed to maintain the process and greenhouse gases are formed during

* Corresponding author 
the treatment, it can be said that conventional activated sludge wastewater treatment is often economically and environmentally unsustainable. According to the calculations of Elías-Maxil et al. [6], 80\% of the energy used in the urban water cycle is spent on heating by the end-user. On the other hand, simulation of domestic water heaters showed that energy intensity can be decreased with the adoption of heat pumps [7]. Reclaiming the waste heat would be a step forward in sustainability and using it within the urban water cycle would facilitate closing the loop.

Wastewater heat recovery can be achieved in three ways:

- In a building (wastewater from bathroom and kitchen);

- From raw wastewater in the urban wastewater distribution line;

- In a wastewater treatment plant from treated wastewater.

For the first version, heat exchangers have to be installed individually which might be difficult in existing buildings and special care has to be taken to avoid biofilm formation [8]. In the case of the second version, the water temperature cannot go below a certain minimum to allow the microorganisms to proliferate in the treatment facility. Thus careful design is needed to use this solution to avoid overcooling, but there are several examples for it [9]. A study showed that up to 35\% of Brussels residences could be served with heat recovery systems installed in the sewer network [10].

The viability of the third method is justified by the temperature dependency of microorganisms. The temperature range of bacteria used in activated sludge systems is within $10-40{ }^{\circ} \mathrm{C}$ [11], the rate of nitrification is doubled every $7{ }^{\circ} \mathrm{C}$ [12] but because oxygen dissolves better in colder water, the operation optimum is between $20-25{ }^{\circ} \mathrm{C}$. The wastewater temperature shows a limited daily variability with variation coefficients between 0.90 and 1.05 [13] while the seasonal change is more significant. The temperature of the influent is dependent on the amount of the wastewater and the length of the sewer system, in winter time it varies between $8-18{ }^{\circ} \mathrm{C}$. Lower values are consequences of long retention time in the sewer system and/or smaller volumes from the households. Because of the continental climate of Hungary, the microorganisms have to adapt to seasonally changing circumstances which usually results in lower performance in the colder periods. Though the limit values for discharging pollutants take this phenomenon into account, the reduced efficiency of nutrient removal contributes to the unsustainability of the present technology. Additionally, the temperature of the effluent in winter time is higher than of the receiving water body causing heat pollution as well.

By implementing a heat pump after the treatment processes, the recovered heat may be used for heating communal buildings within the facility, providing hot water, sludge drying or for district heating/cooling. It is calculated that there are over 500 wastewater heat pump systems worldwide with thermal ratings between $10 \mathrm{~kW}-20 \mathrm{MW}$ [14] for instance in Germany, Switzerland and the Scandinavian countries [8]. A Swiss study [9] found that Carbon dioxide $\left(\mathrm{CO}_{2}\right)$ emission of a bivalent wastewater heat pump system is $22 \%$ of an oil-fired heating system. Zhao et al. [15] showed that the heating Coefficient of Performance (COP) is about 4.3, and the cooling COP is about 3.5 in actual operating conditions which is comparable to the COP of a ground source heat pump $[16,17]$.

In an Austrian example the use of wastewater as the low-temperature heat source of the heat pump provided a total $45 \mathrm{MW}$ of space heating with $9 \mathrm{MW}$ of electricity input [18]. By applying spatial analysis the feasibility of integrating a Wastewater Treatment Plant (WWTP) local energy supply systems can be evaluated [19].

The systems utilizing the excess heat of wastewater are usually applied to larger facilities [14]. Small municipal WWTPs are prone to decreased water temperature due to relatively long retention time in the sewers and the fluctuation of flow rate as a result of variation in daily and weekly residential water use. Since the volume of wastewater is 
less but varies more, the system is subject to abrupt changes. Unfortunately, they also often lack sophisticated monitoring systems which may result in inefficient operation or even unwanted environmental pollution. This paper discusses the possibility of applying heat pumps to reclaim the excess heat, which would be normally released to the environment and use it to increase the temperature in the biological train to avoid malfunctions due to overcooling. Dynamic simulation, a valuable tool to investigate solutions alternative to the business-as-usual operation [20], was used to assess the effect of higher temperature.

\section{MATERIALS AND METHODS}

The WWTP chosen for the study has an average hydraulic load of 2,300 $\mathrm{m}^{3} / \mathrm{d}$. It consists of two parallel annular aerated basins of $3,000 \mathrm{~m}^{3}$ volume with diffused aeration and banana mixers, each encompassing a Dorr-type settler (Figure 1). Only one of these is in operation due to decreased amount of incoming wastewater. The WWTP is designed to have intermittent denitrification. If the Dissolved Oxygen (DO) concentration reaches $3.6 \mathrm{~g} / \mathrm{m}^{3}$ aeration is turned off. It starts again when the DO goes below $0.6 \mathrm{~g} / \mathrm{m}^{3}$ or after 50 minutes. The hydraulic retention time in the aeration tank is between 24-29 hours, the sludge age is around 20 days.

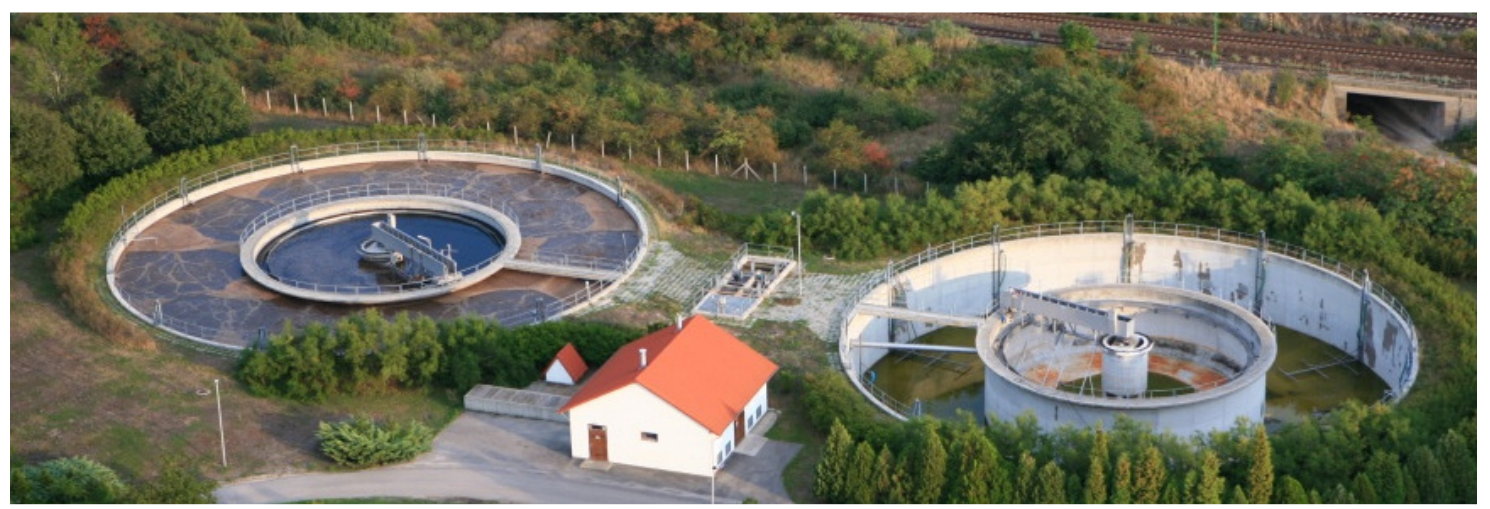

Figure 1. Aerial view of the Varpalota WWTP - on the left is the system in operation, the other is out of service (source: Bakonykarszt Ltd.)

The WWTP has no online measurement devices beside the DO probe for the aeration control and the flowmeter. Samples are taken twice a week to determine wastewater quality which does not give information on the daily fluctuation or the operational problems outside the measurement period. The plant was chosen to be a pilot to test the mobile laboratories and online warning system of an R\&D project (GOP-1.3.1-08/B-2009-0027) in 2012.

The mobile laboratories measured Chemical Oxygen Demand (COD), ammonium, orthophosphate, nitrite and nitrate and sulphide in the influent stream and COD, ammonium, orthophosphate and nitrate regarding the effluent. Besides that, $\mathrm{pH}$, conductivity, temperature and turbidity were monitored on both sides and dissolved oxygen concentration in the aerated tanks. The samples were taken hourly and measurement results could be accessed through an online communication system.

Activated Sludge Model No.1 (ASM1) [21] was chosen for modelling since there is no biological excess phosphorous removal. ASM1 is a grey box model describing organic matter and nitrogen removal by heterotrophic and autotrophic bacteria in a death-regeneration approach, omitting the storage of substrate in the growth process. The reactor was split up into four quarters (Figure 2) in order to take the plug-flow nature of the annular shape into consideration. Influent characterisation was carried out based on 
the results of Pásztor et al. [22]. Since the data for raw wastewater flow was provided in daily averages by the management of the plant, the method of Langergraber et al. [23] was used to provide hourly values [eq. (1) and Figure 3]:

$$
\dot{V}(t)=\dot{V}_{\mathrm{a}}+b_{1} \times \sin (\omega t)+b_{2} \times \cos (\omega t)+b_{3} \times \sin (2 \omega t)+b_{4} \times \cos (2 \omega t)
$$

where $\omega$ is the angular frequency [eq. (2)]:

$$
\omega=2 \pi / T
$$

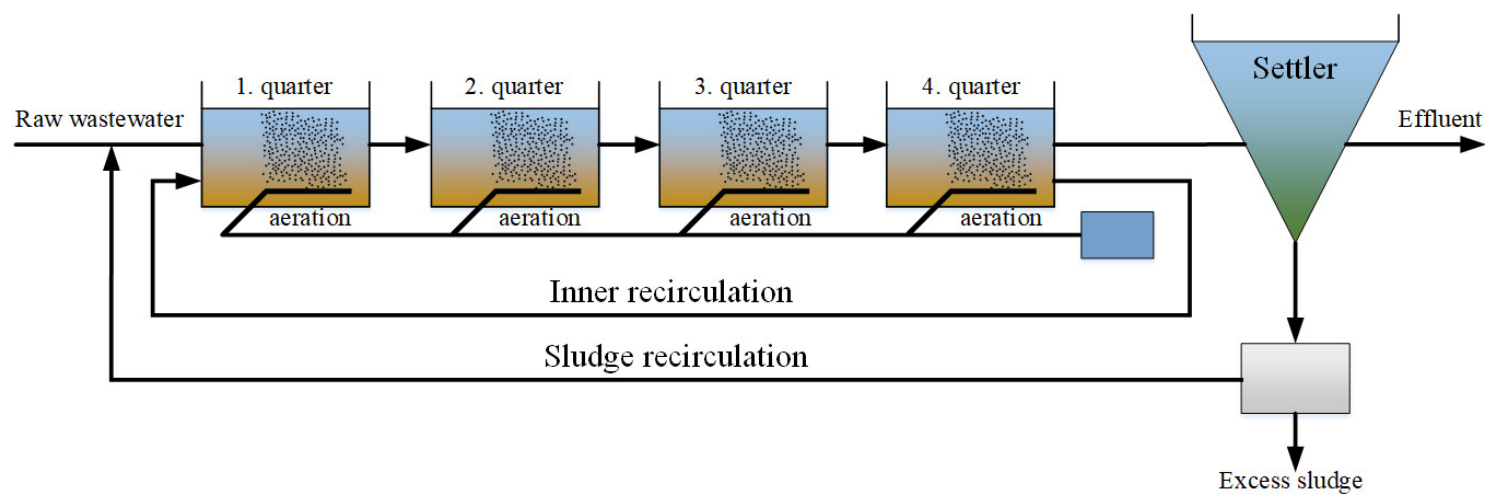

Figure 2. Schematic representation of the examined WWTP

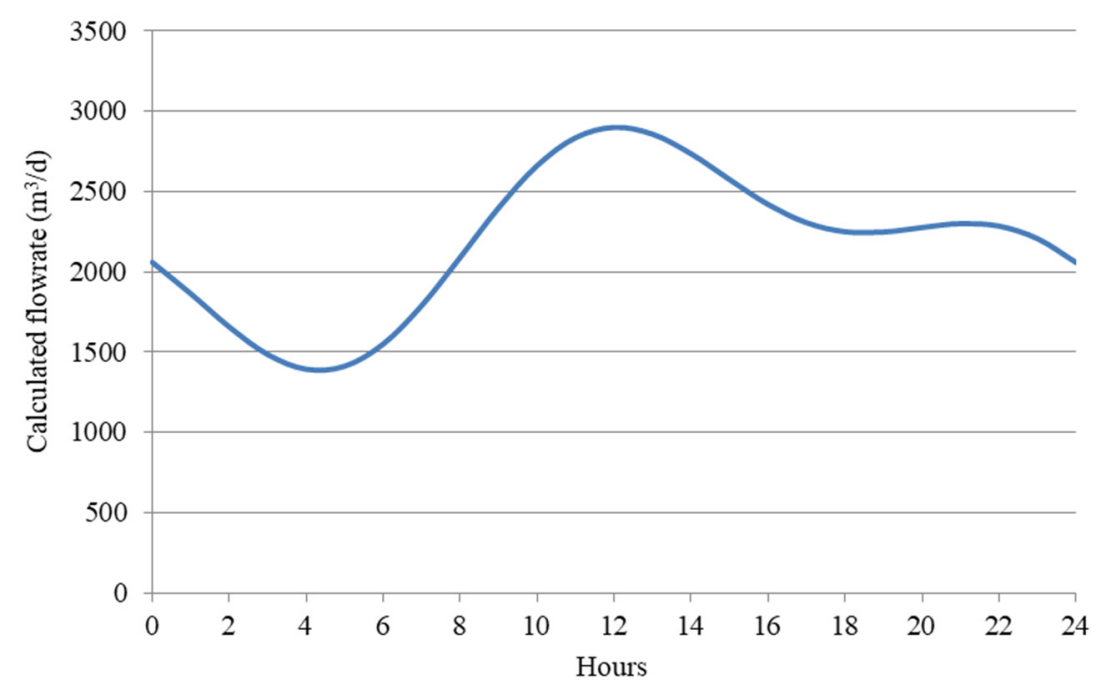

Figure 3. Estimated daily wastewater fluctuation $\left(\dot{V}_{\mathrm{a}}=2,190 \mathrm{~m}^{3} / \mathrm{d}, b_{1}=-350.00, b_{2}=-420.00\right.$,

$$
\left.b_{3}=-160.00, b_{4}=290.00, T=1 \mathrm{~d}, \omega=2 \pi \mathrm{rad} / \mathrm{d}\right)
$$

Temperature dependency was taken into consideration according the Arrhenius equation [eq. (3)] [24] for autotrophic and heterotrophic biomass growth and decay and hydrolysis rate. The temperature in the examined period varied between $10-14{ }^{\circ} \mathrm{C}$ (Figure 4):

$$
r=r_{20} \times \exp [k \times(\theta-20)]
$$

In order to maintain the nitrification the excess sludge removal rate was kept low in wintertime. While normally the plant would have satisfactory nitrification capacity, the quality of the effluent decreased in several cases. 


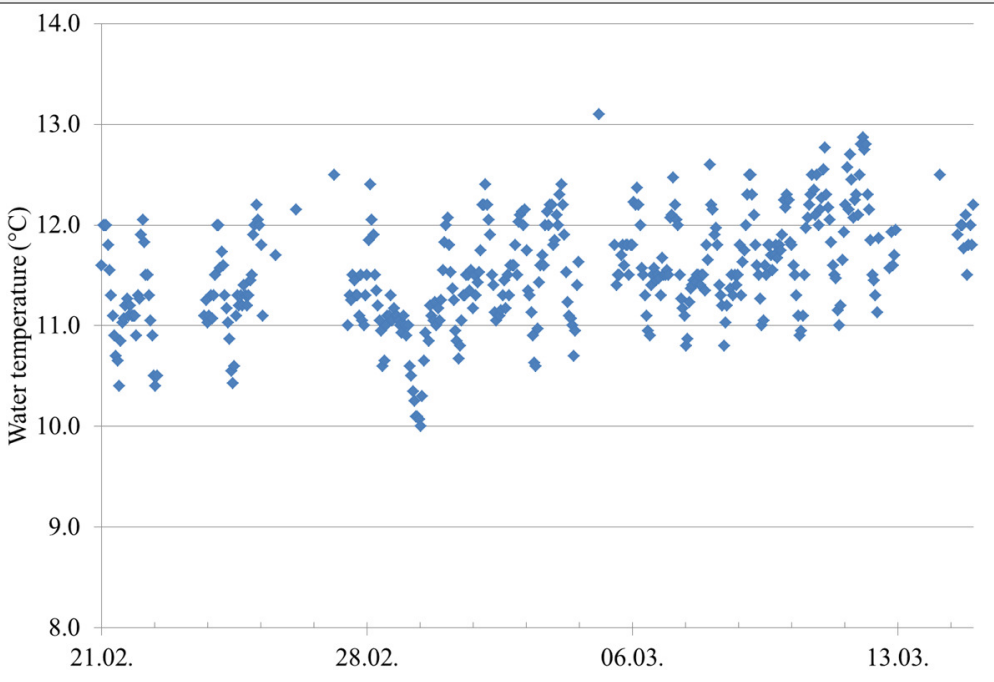

Figure 4. Wastewater temperature during the examined period

\section{RESULTS}

Simulation was carried out in the time interval of $21^{\text {st }}$ February- $14^{\text {th }}$ March 2012. The differences between simulation and measurement results were within $6.65 \%$ error in case of ammonium-nitrogen with $95 \%$ confidence. For nitrate-nitrogen these values were $\alpha=0.05$ and $\varepsilon=13.65 \%$. Deviation from measured results was due to fact that hydraulic retention time is a function of flow rate and pairing the data could not be done in a straightforward manner. Also, while the DO control of the model was created to mimic reality, it was not possible to implement the inertia of the aeration system. Thus, while in real life DO concentration higher than $3.6 \mathrm{~g} / \mathrm{m}^{3}$ was registered occasionally $\left(22^{\text {nd }}\right.$ February and $1^{\text {st }}$ March) the model results stayed under the threshold. In these instances the model ammonium concentrations were distinctively higher than the measured results.

There were two occasions when sludge bleed-through was experienced $\left(4^{\text {th }}\right.$ and $11^{\text {th }}$ March) based on the samples taken for cross-validation (Figure 5 and 6, values labelled 'laboratory'). According to the data of the analysers, the phenomena occurred before for several times. The management chose to keep the sludge concentration high to compensate the effect of colder water $\left(10-14{ }^{\circ} \mathrm{C}\right)$ but without supervision the sludge blanket rose high and the effluent suspended solids concentration increased temporarily. Table 1 shows the frequency of excess sludge removal. The last two were carried out because of the samples taken at that time.

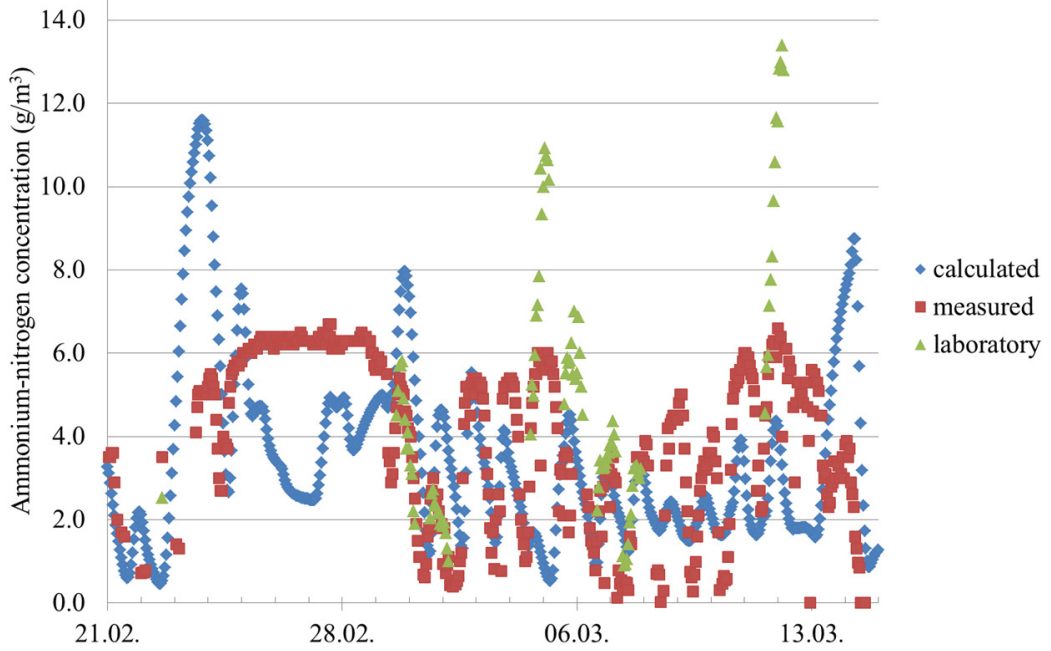

Figure 5. Ammonium-nitrogen concentration 


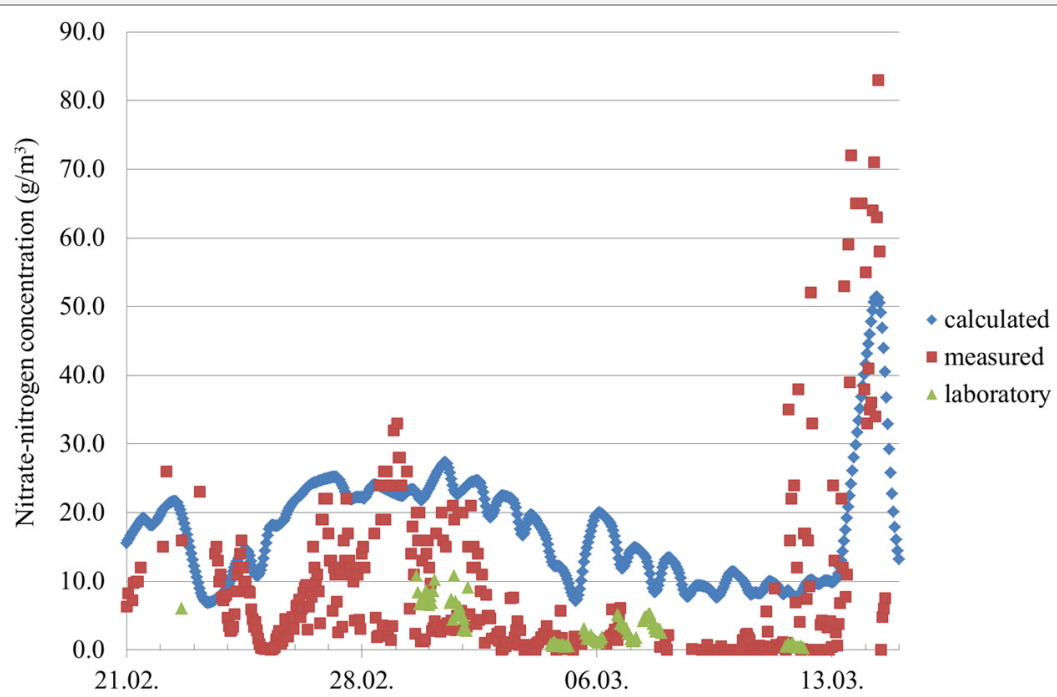

Figure 6. Nitrate-nitrogen concentration

Table 1. Timespan of excess sludge removal

\begin{tabular}{cc}
\hline Date & Interval (hours) \\
\hline $31^{\text {st }}$ January & 2.0 \\
$27^{\text {th }}$ February & 5.4 \\
$12^{\text {nd }}$ March & 4.0 \\
$13^{\text {rd }}$ March & 3.4 \\
\hline
\end{tabular}

According to simulation and online measurement results such processes took place between $23^{\text {rd }}-24^{\text {th }}$ February (Thursday and Friday) and $29^{\text {th }}$ February (Wednesday evening), $4^{\text {th }}-5^{\text {th }}$ March (Sunday until Monday morning) and $10^{\text {th }}-12^{\text {th }}$ March (weekend). The peak in the ammonium curve on $14^{\text {th }}$ March indicates that the model was more sensitive to the excess sludge removal than the real system itself.

Though there are no limit values set for nitrogen forms in the case of Várpalota WWTP, the aim of management was to maintain efficiency by keeping the sludge concentration high. Based on the results this had the opposite effect. Sludge age could be kept lower and more excess sludge could be removed from the system if the nitrification rate could be improved. This may be done by increasing the water temperature in the aerated tank.

Considering the lowest measured wastewater temperature $\left(10^{\circ} \mathrm{C}\right)$, the temperature of the effluent could be decreased by $6{ }^{\circ} \mathrm{C}$ safely. The smallest estimated flowrate was $2,158 \mathrm{~m}^{3} / \mathrm{d}$. That means that $627 \mathrm{~kW}$ could be retrieved even using a conservative estimate [eq. (4)]:

$$
Q=\dot{m}_{\mathrm{w}} \times c_{\mathrm{w}} \times\left(\theta_{\mathrm{h}}-\theta_{\mathrm{c}}\right)=24,919 \frac{\mathrm{g}}{\mathrm{s}} \times 4.195 \frac{\mathrm{J}}{\mathrm{g}^{\circ} \mathrm{C}} \times\left(10{ }^{\circ} \mathrm{C}-4{ }^{\circ} \mathrm{C}\right)=627 \mathrm{~kW}
$$

This is the overall minimum, thus this amount of energy could be used to raise the water temperature in the aerated tank with the help of heat pumps and heat exchangers even if losses are accounted for. Of course, the exact amount of reclaimable heat depends on several factors, including the temperatures of the wastewater and the receiving surface water, heat loss, efficiency of heat pumps and foaming [25], among others. Assuming that the temperature in the aeration basin can be raised by $6{ }^{\circ} \mathrm{C}$, it would theoretically result in an $80 \%$ increase in the growth rate according to eq. (5) [24]:

$$
\mu_{\mathrm{A}}=\mu_{\mathrm{A} 20} \times \exp [0.0981 \times(\theta-20)]
$$


In order to achieve the temperature increase in the aerated tank, a heat pump system would be installed to the space between the biological tank and the divider unit (Figure 7). It is assumed to be open from the effluent side since solids are removed in the settler but closed from the wastewater side to mitigate fouling. The Heat Exchanger (HE) has to be easy to clean or even self-cleaning as biofilm formation is unavoidable and it should not hinder mixing of the liquor and aeration inside the tank but effectively facilitate heat transfer in the reactor. Further research is required to choose the appropriate type, but alternatively to the submerged version depicted in Figure 7, the HE may be introduced to where the influent and the return sludge are mixed or an external solution may be applied. While due to the elevated temperature the amount of heat loss is expected to increase, that would be compensated by the heat production of increased biological activity. Previous results showed that the water temperature from influent to effluent increases between 0.8 and $1.5^{\circ} \mathrm{C}$ [26]. Heat loss during the transfer of working fluids should be minimised by using insulated pipes.

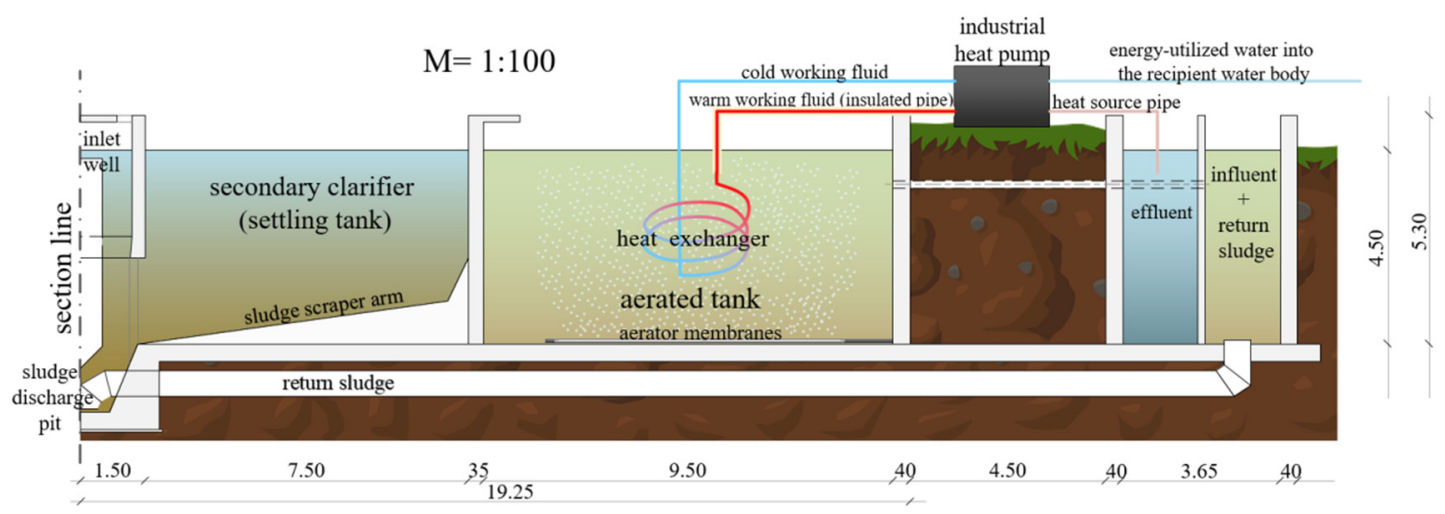

Figure 7. Schematic design of introducing heat pump and heat exchangers to utilize waste heat in the aerated tank

After rerunning the simulation with the elevated temperature values, the results showed that, even with leaving the excess sludge removal rate as it was in the original case, the highest value would be $5.47 \mathrm{~g} \mathrm{~N} / \mathrm{m}^{3}$ for ammonium concentration (Figure 8) and $48.25 \mathrm{~g} \mathrm{~N} / \mathrm{m}^{3}$ for nitrate (Figure 9). The comparison was made to the results of the original simulation (marked as default in the figures). On average, $61 \%$ decrease could be achieved in ammonium and $17 \%$ in nitrate concentration (Table 2).

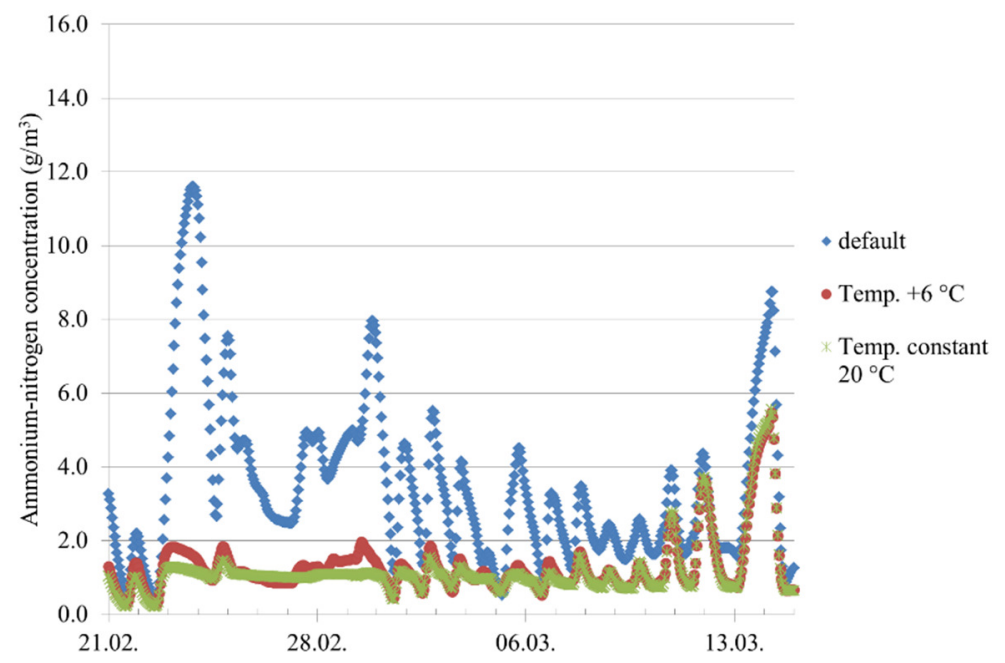

Figure 8. Changes in ammonium-nitrogen concentration if temperature is increased in the aeration tank 


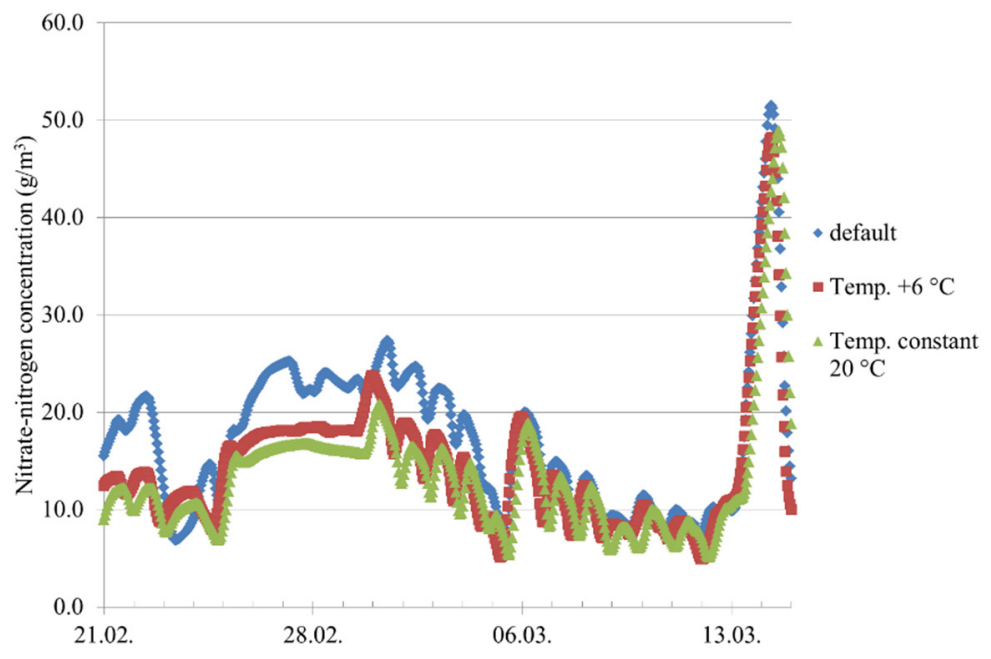

Figure 9. Changes in nitrate-nitrogen concentration if temperature is increased in the aeration tank

If the wastewater in the aerated tank is reheated constantly it is safe to say that more heat can be reclaimed from the effluent without decreasing the water temperature below $4{ }^{\circ} \mathrm{C}$. Also, if the wastewater temperature is increased by $6{ }^{\circ} \mathrm{C}$, the input of the heat pump would be $16{ }^{\circ} \mathrm{C}$, neglecting changes due to heat gains and losses. That means more energy could and should be reclaimed to avoid heat pollution in the receiving water body. Thus another scenario was tested; the water temperature would be kept at $20{ }^{\circ} \mathrm{C}$ which is considered to be an operational optimum. It is a compromise between the higher temperature optimum of the bacteria and the fact that oxygen dissolves more in colder waters. Simulation results showed that at $20^{\circ} \mathrm{C}$ the maximum ammonium concentration would be $5.56 \mathrm{~g} \mathrm{~N} / \mathrm{m}^{3}$, while the average value would be $1.19 \mathrm{~N} / \mathrm{m}^{3}$, meaning a $64 \%$ decrease (Figure 8). Regarding nitrate concentration these numbers would be $48.87 \mathrm{~g} \mathrm{~N} / \mathrm{m}^{3}, 13.20 \mathrm{~g} \mathrm{~N} / \mathrm{m}^{3}$ and $22 \%$, respectively (Figure 9). Results of the scenarios are summarised in Table 2 .

Table 2. Enhanced nitrogen removal due to increased temperature

\begin{tabular}{ccccccc}
\hline & \multicolumn{3}{c}{ Ammonium-nitrogen } & \multicolumn{3}{c}{ Nitrate-nitrogen } \\
\hline & default & $\begin{array}{c}6{ }^{\circ} \mathrm{C} \\
\text { increase }\end{array}$ & $\begin{array}{c}\text { constant } \\
20{ }^{\circ} \mathrm{C}\end{array}$ & default & $\begin{array}{c}6{ }^{\circ} \mathrm{C} \\
\text { increase }\end{array}$ & $\begin{array}{c}\text { constant } \\
20{ }^{\circ} \mathrm{C}\end{array}$ \\
\hline $\begin{array}{c}\text { Maximum } \\
{\left[\mathrm{g} \mathrm{N} / \mathrm{m}^{3}\right]} \\
\text { Average } \\
{\left[\mathrm{g} \mathrm{N} / \mathrm{m}^{3}\right]}\end{array}$ & 11.60 & 5.47 & 5.56 & 51.48 & 48.25 & 48.87 \\
$\begin{array}{c}\text { Improvement } \\
{[\%]}\end{array}$ & 3.34 & 1.30 & 1.19 & 16.98 & 14.11 & 13.20 \\
\hline
\end{tabular}

The efficiency did not increase significantly in the second scenario. The average ammonium concentration improved by only $3 \%$ points while the mean nitrate concentration decreased by $5 \%$ points. This leads to the assumption that after reheating the aerated tank to a sufficiently high temperature (between $16-20{ }^{\circ} \mathrm{C}$ ), the excess heat could be used for other purposes such as providing auxiliary energy to heating the buildings.

\section{CONCLUSIONS}

Apart from the temporary spilling of sludge, the results show that the plant operates sufficiently. Keeping high sludge concentration in the aerated tank is necessary, but to 
avoid the overload of the settler the authors recommend measuring sludge settleability. The sludge volume after thirty minutes settling $\left(\mathrm{SV}_{30}\right)$ provides quick information on the settling properties. It is advised to start sludge removal if the $\mathrm{SV}_{30}$ for diluted sludge is over 300-400 ml/l. To define the critical value when overflow starts, the $\mathrm{SV}_{30}$ should be measured frequently. Later, measurements can be carried out before weekends so that the bleed-through can be prevented.

Regarding the utilization of the excess heat of the effluent the results showed that one solution can be providing sufficient temperature to facilitate the biological processes in the aerated tank. This would increase the robustness of the plant operation and eliminate the vulnerability caused by overcooled wastewater from the sewer system. Increasing the water temperature in the aerated tank by $6^{\circ} \mathrm{C}$ the ammonium removal efficiency could be improved by $61 \%$ on average under the studied circumstances. Nitrate concentration decreased by $17 \%$ with the same parameters. Keeping the temperature at a constant $20^{\circ} \mathrm{C}$ did not result in significant improvement which opens the possibility to use the excess heat for other purposes beside enhanced pollution removal, for example to provide heating in auxiliary buildings such as the dewatering facility or even for producing domestic hot water in the facility. To determine the configuration of the system that is capable of introducing the excess heat to the aerated tank and its feasibility needs further examination.

\section{ACKNOWLEDGEMENT}

The measurement campaign was financially supported by the project GOP-1.3.1-08/B-2009-0027. The authors would also like to acknowledge the financial support of Széchenyi 2020 under the GINOP-2.3.2- 15-2016-00016.

\section{NOMENCLATURE}

$b$

$c$

COD

DO

$k$

$\dot{m}$

$r$

$Q$

SV

$t$

$T$

$\dot{V}$

\section{Greek letters}

$\alpha$

$\varepsilon$

$\mu$

$\theta$

$\omega$

\section{Subscripts}

empirical constants

specific heat capacity

chemical oxygen demand

dissolved oxygen concentration

Arrhenius constant

mass flow rate

rate of reaction

potential reclaimable heat energy

sludge volume after settling

time instance

time period

wastewater flow rate
$[-]$

$\left[\mathrm{J} / \mathrm{g}{ }^{\circ} \mathrm{C}\right]$

$\left[\mathrm{g} \mathrm{O}_{2} / \mathrm{m}^{3}\right]$

$\left[\mathrm{g} \mathrm{O}_{2} / \mathrm{m}^{3}\right]$

[-]

$[\mathrm{g} / \mathrm{s}]$

[-]

$[\mathrm{kW}]$

[ml/l]

[d]

[d]

$\left[\mathrm{m}^{3} / \mathrm{d}\right]$

significance level

$[-]$

[\%]

$[1 / \mathrm{d}]$

$\left[{ }^{\circ} \mathrm{C}\right]$

$[\mathrm{rad} / \mathrm{d}]$

maximum specific growth rate of bacteria

temperature

angular frequency

at $20{ }^{\circ} \mathrm{C}$

after thirty minutes settling

autotrophic microorganisms

daily average 
$\mathrm{c}$

$\mathrm{h}$

W

after heat reclamation (cold)

before heat reclamation (hot)

wastewater

\section{REFERENCES}

1. Bixio, D., Thoeye, C., De Koning, J., Joksimovic, D., Savic, D., Wintgens, T. and Melin, T., Wastewater reuse in Europe, Desalination, Vol. 187, No. 1-3, pp 89-101, 2006, https://doi.org/10.1016/j.desal.2005.04.070

2. Drechsel, P., Mahjoub, O. and Bernard, K., Social and Cultural Dimensions in Wastewater use, Wastewater: Economic Asset in an Urbanizing World (Drechsel, P., Qadir, M. and Wichelns, D., eds.), pp 75-92, Springer Netherlands, Dordrecht, 2015, https://doi.org/10.1007/978-94-017-9545-6

3. Lahnsteiner, J. and Lempert, G., Water management in Windhoek, Namibia, Water Sci. Technol., Vol. 55, No. 1-2, pp 441-448, 2007, https://doi.org/10.2166/wst.2007.022

4. Friedler, E., Lahav, O., Jizhaki, H. and Lahav, T., Study of Urban Population attitudes towards various Wastewater reuse Options: Israel as a Case Study, J. Environ. Manage., Vol. 81, No. 4, pp 360-370, 2006, https://doi.org/10.1016/j.jenvman.2005.11.013

5. Sheik, A. R., Muller, E. E. L. and Wilmes, P., A Hundred Years of activated Sludge: Time for a rethink, Front. Microbiol., Vol. 5, Art. 47, pp 1-7, 2014, https://doi.org/10.3389/fmicb.2014.00047

6. Elías-Maxil, J. A., van der Hoek, J. P., Hofman, J. and Rietveld, L., Energy in the Urban Water Cycle: Actions to reduce the Total Expenditure of Fossil Fuels with emphasis on Heat Reclamation from Urban Water, Renew. Sustainable Energy Rev., Vol. 30, pp 808-820, 2014, https://doi.org/10.1016/j.rser.2013.10.007

7. Vieira, A. S., Humphrys, S., Beal, C. D. and Stewart, R. A., Optimising Residential Water Heating System Performance to minimise Water-energy Penalties, J. Sustain. Dev. Energy Water Environ. Syst., Vol. 4, No. 2, pp 161-172, 2016, https://doi.org/10.13044/j.sdewes.2016.04.0013

8. Seybold, C. and Brunk, M. F., In-house Waste Water Heat Recovery, REHVA Journal, pp 18-21, 2013.

9. Schmid, F., Sewage Water: Interesting Heat Source for Heat Pumps and Chillers, Swiss Energy Agency for Infrastructure Plants, Zürich, Switzerland, 2008.

10. Spriet, J. and Hendrick, P., Wastewater as a Heat Source for Individual Residence Heating: A Techno-economic feasibility Study in the Brussels Capital Region, J. Sustain. Dev. Energy Water Environ. Syst., Vol. 5, No. 3, pp 289-308, 2017, https://doi.org/10.13044/j.sdewes.d5.0148

11. van Haandel, A. C. and van der Lubbe, J. G., Handbook of Biological Wastewater Treatment: Design and Optimisation of Activated Sludge Systems, Water Intelligence Online 11, 2012.

12. Henze, M., van Loosdrecht, M. C. M., Ekama, G. A. and Brdjanovic, D., eds., Biological Wastewater Treatment, Principles, Modelling and Design, IWA Publishing, London, UK, 2008.

13. Cipolla, S. S. and Maglionico, M., Heat Recovery from Urban Wastewater: Analysis of the Variability of Flow Rate and Temperature, Energ. Buildings, Vol. 69, pp 122-130, 2014, https://doi.org/10.1016/j.enbuild.2013.10.017

14. Hepbasli, A., Biyik, E., Ekren, O., Gunerhan, H. and Araz, M., A Key review of Wastewater Source Heat Pump (WWSHP) Systems, Energ. Convers. Manage, Vol. 88, pp 700-722, 2014, https://doi.org/10.1016/j.enconman.2014.08.065

15. Zhao, X. L., Fu, L., Zhang, S. G., Jiang, Y. and Lai, Z. L., Study of the Performance of an Urban Original Source Heat Pump System, Energ. Convers. Manage., Vol. 51, No. 4, pp 765-770, 2010, https://doi.org/10.1016/j.enconman.2009.10.033 
16. Wołoszyn, J. and Gołaś, A., Coefficient of Performance stabilisation in Ground Source Heat Pump Systems, J. Sustain. Dev. Energy Water Environ. Syst., Vol. 5, No. 4, pp 645-656, 2017, https://doi.org/10.13044/j.sdewes.d5.0173

17. Bedoić, R. and Filipan, V., Heating Performance Analysis of a Geothermal Heat Pump working with different Zeotropic and Azeotropic Mixtures, J. Sustain. Dev. Energy Water Environ. Syst., https://doi.org/10.13044/j.sdewes.d5.0189

18. Nowak, O., Enderle, P. and Varbanov, P., Ways to optimize the Energy Balance of Municipal Wastewater Systems: Lessons learned from Austrian Applications, J. Clean. Prod., Vol. 88, pp 125-131, 2015, https://doi.org/10.1016/j.jclepro.2014.08.068

19. Kollmann, R., Neugebauer, G., Kretschmer, F., Truger, B., Kindermann, H., Stoeglehner, G., Ertl, T. and Narodoslawsky, M., Renewable Energy from Wastewater-Practical aspects of integrating a Wastewater treatment Plant into Local Energy Supply Concepts, J. Clean. Prod., Vol. 155, pp 119-129, 2017, https://doi.org/10.1016/j.jclepro.2016.08.168

20. Hvala, N., Vrečko, D., Levstek, M. and Bordon, C., The use of Dynamic Mathematical Models for improving the designs of upgraded Wastewater treatment Plants, J. Sustain. Dev. Energy Water Environ. Syst., Vol. 5, No. 1, pp 15-31, 2017, https://doi.org/10.13044/j.sdewes.d5.0130

21. Henze, M., Grady, C. P. L., Gujer, W., Marais, G. v. R. and Matsuo, T., Activated Sludge Model No. 1, IAWPRC Scientific and Technical Report No. 1, IAWPRC, London, UK, 1987.

22. Pásztor, I., Thury, P. and Pulai, J., Chemical Oxygen demand Fractions of Municipal Wastewater for modelling of Wastewater treatment, Int. J. Environ. Sci. Te., Vol. 6, No. 1, pp 51-56, 2009, https://doi.org/10.1007/BF03326059

23. Langergraber, G., Alex, J., Weissenbacher, N., Woerner, D., Ahnert, M., Frehmann, T., Halft, N., Hobus, I., Plattes, M., Spering, V. and Winkler, S., Generation of Diurnal Variation for influent Data for Dynamic Simulation, Water Sci. Technol., Vol. 57, No. 9, pp 1483-1486, 2008, https://doi.org/10.2166/wst.2008.228

24. Nic, M., Jirat, J. and Kosata, B., IUPAC Compendium of Chemical Terminology, (the "Gold Book", $2^{\text {nd }}$ ed.), 2006.

25. Corbala-Robles, L., Volcke, E. I. P., Samijn, A., Ronsse, F. and Pieters, J. G., Effect of Foam on Temperature prediction and Heat recovery potential from Biological Wastewater treatment, Water Res., Vol. 95, pp 340-347, 2016, https://doi.org/10.1016/j.watres.2016.03.031

26. Fernández-Arévalo, T., Lizarralde, I., Grau, P. and Ayesa, E., New Systematic Methodology for incorporating Dynamic Heat transfer modelling in Multi-phase Biochemical Reactors, Water Res., Vol. 60, pp 141-155, 2014, https://doi.org/10.1016/j.watres.2014.04.034 